ISSN 1112-9867

Available online at http://www.jfas.info

\title{
METHOD OF OPTIMAL OPERATION OF SMALL DAM IN IRRIGATION
}

\author{
M. Ladjel \\ Hydraulic Department, Abderrahman University Mira- Bejaia- Algeria
}

Received: 04 October 2014 / Accepted: 29 December 2014 / Published online: 15 January 2015

\begin{abstract}
In several Arab countries; agriculture is considered as the largest user of sweet water. This noble resource is distributed erratically by time and space. For the month of irrigation, this resource became scanty. That's why; it is require to storage it; protect it and use it reasonably based on a deep knowledge of hydro meteorological policy and irrigation. This contribution is to propose the hydrological method of exploitation if the resource of water regulate by a small water dam. This is ascertained by the equation of the hydratical balance. Because it is possible to improve the yield of the water dam by the apliment of operating rules during irrigation season based on probabilistic projections of the fundamental components of the water balance.
\end{abstract}

Key words: flow, small dam, irrigation, water balance.

\section{INTRODUCTION}

A high percentage of Arab countries population is occupied by agriculture, which must be guaranteed irrigation water to ensure sufficient corps. For that, we must use the resource mobilization of water on surface in water dams of various sizes, which represent the only way for the promotion of agricultural production. Indeed, it is inconceivable to rely solely on direct irrigation by the seasonal rains and let water flow freely to the sea and the lakes, while it is useful for farmers. Temporary storage of these water in dams, it doesn't allow only its direct use but it allows the filling of groundwater and ensures the preservation of this precious resource.

Author Correspondence, e-mail: ladjel_mahmoud@yahoo.fr

Tel.: +2130666513160

ICID: 1134332 
We consider that in a semiarid climate region a relative increase in the capacity of the water dam, can be beneficial, because it allows storing an excess of water; otherwise it will be destiny for siltation. The hydrological standards "international" are developed and checked in climatic conditions of temperate countries where there is a relative abundance of precipitation during the twelve months of the year. Their application in Arab countries a semiarid climate must be the subject of a critical analysis and of a comprehensive study on the recommended objective or to solve problems. For example, we remark that hydrometric rivers in geometrically deformable beds, remains a problematic. However, the correct genetic commodity of the hydromatic regime, based on appropriate measures, would consider a rational exploitation of water resource [1]. In addition, the operation of a dam or a dam system must use forecasts hydro meteorological as medium term.

\section{ESTABLISHMENT OF WATER BALANCE OF A DAM}

It considers a dam as a dynamic system whose basic components vary continuously over time. For convenience, we discredited time in monthly intervals. In the beginning, the dam has a volume of water $V_{i}$ that add the flow $\mathrm{E}$ and precipitation $\mathrm{P}$ during the month. But at the same time, the water dam is given a quantity of water, in the form of restitution $R_{s}$ to the user, a part of the water stored in the dam are evaporated directly from the water $P_{e v}$ and the other part infiltrates into the subsoil and groundwater supplies [2,3]. The figure below shows the main components of the water balance for Dam.

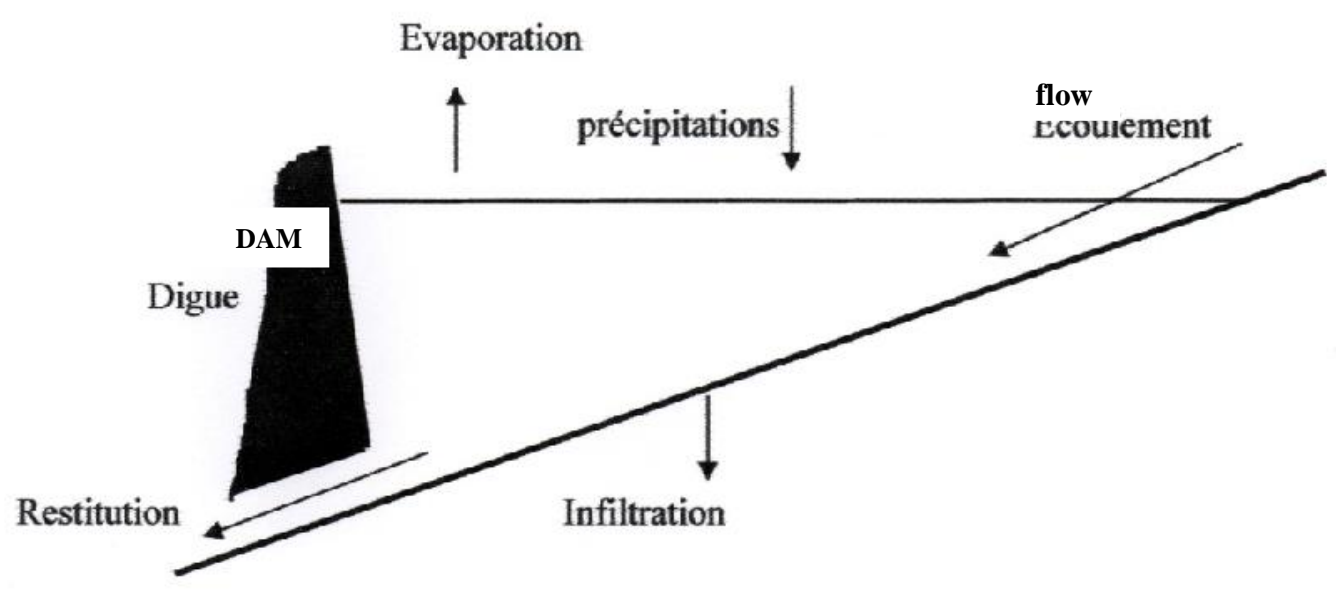

Fig. 1. The main components of water balance of water dam 
The monthly water balance in the water dam equation is expressed as follows [8]:

$$
V_{i+1}=V_{i}+P_{i+1} \cdot \bar{\Omega}+E_{i+1}-R_{s, i+1}-P_{e v, i+1}-P_{f i l, i+1}
$$

Where:

$V_{i}$-The volume of water at the beginning of the month;

$V_{i+1}$-The volume of water at the end;

$P_{i+1}$ - Blade precipitated during the month $i+1$;

$\bar{\Omega}$ - The mean surface of the water during the month $i+1$;

$E_{i+1}$ - Water intake during the month $i+1$;

$A_{i+1}$ - Restitution, during the month $i+1$;

$P_{e v, i+1}$ - The amount of evaporation during the month $i+1$;

$P_{f i l, i+1}$ - The volume of water filtered during the month $i+1$;

\section{IDENTIFICATION OF WATER BALANCE COMPONENTS}

\section{*ESTIMATES OF FLOW}

It considers that the flow in the dam during the month $i+1$, depend on the precipitation of frequency data $\mathrm{P} \%$ during that same month and the basin physic of the previous $[1,9]$ month statement. We can use the model of storm flow [4, 5, 6, and 7], we write:

was

$$
E_{i+1, P \%}=\alpha_{i+1, P \%} \cdot P_{i+1, P \%}
$$

and

$$
\alpha_{i+1, P \%}=1-P_{i+1, P \%}^{m-1}
$$

$$
m_{i}=1-\frac{C_{i}}{\ln P_{i}}
$$

where:

$E_{i+1, P \%}$ - Flow that month $i+1$;

$P_{i+1, P \%}$ - The precipitation during the same month $i+1$;

$\alpha_{i+1, P \%}$ - Coefficient of the monthly flow $i+1$;

$P_{i}$ - Precipitation of the previous month $i$;

$m_{i}$ - Parameter dependent on the initial state of saturation of the watershed losses; 


$$
C_{i}=\ln \left(1-\frac{E_{i}}{P_{i}}\right)-\text { Monthly average rainfall remained in the watershed during the previous }
$$

time interval $i$.

The application of this model's prediction, after identification of the two parameters $m_{i}$ and $c_{i}$, it must be verified by the following criteria $[6,7]$ as:

$$
\sum\left|\left(E_{\text {observé }}-E_{\text {calculé }}\right)\right| \rightarrow \min
$$

The choice of frequency $\mathrm{P} \%$, attributed to the monthly rainfall, depends on the risk to lose. Its value ranges from:

$* \mathrm{P}=100 \%$ for zero risk, that correspond with the minimum value of precipitation guarantees $100 \%$, which mean it is limited only for the use of flow warranty.

$* \mathrm{P}=50 \%$ this limitation correspond with the average monthly precipitation amount, the risk is certain for any deviation from the actual observed value must cause a deficiency of restitution on one or several months.

For the first case, $\mathrm{P}=100 \%$, the operation is limited to the use of water minimum stored in the dam, since the beginning of irrigation season (early April), without taking into account the following month rains. Therefore, we must seek optimal value frequency $\mathrm{P} \%$, in order to reduce the margin of risk, while using rain likely falling during the month; knowing that the frequencies of monthly precipitation vary considerably. But they are subject a cyclicality seasonal which shows the existence of any auto correlation between monthly rainfalls. We consider that frequency of the month rainfall of the order of $\mathrm{P}=75 \%$ may well ensure a minor risk towards the need of irrigation.

\section{*DETERMINATION OF LOSS OF WATER IN DAM}

It was agreed to consider that the losses of water in dam are evaporative losses $P_{e v}$, from the plan of water and filtration $P_{f i l}$ in the bowl and through the dyke.

The volume of losses by filtration depends on the hydro geological of the site conditions it represents $\gamma$ a share of monthly average volume $\bar{V}$ in the dam [8], is the calculus:

$$
P_{\text {fil }}=\gamma \bar{V}
$$

The determination of the coefficient $\gamma$ can be established on the basic of regional water less study in existing dam; on the basic of the analysis of the water balance of the dam. The 
volume of evaporation loss is function of the monthly average temperature $t^{\circ}$ of the air and the average area $\bar{\Omega}$ of water in dam [8]. Either:

$$
P_{e v}=f\left(t^{\circ}, \bar{\Omega}\right)
$$

With $\bar{\Omega}=\frac{\Omega_{i}+\Omega_{i-1}}{2}$ and $\bar{V}=\frac{V_{i}+V_{i-1}}{2}$. Knowing that there is also calculus: $\Omega=f(V)$.

It is possible to take into consideration two loss types and express them by a single calculus on the basic of the average volume $\bar{V}$.

The graph-analytical analysis of monthly total water loss $P_{T}$ is existing dams, allows the separation of the loss by filtration and evaporation for the purpose of identification of two calculi (5) \& (6). By giving different values $\gamma^{(i)}$ to $\gamma$, there are differences between the total losses $P_{T}$ and the loss by filtration $P_{f i l}{ }^{(i)}=\gamma^{(i)} \bar{V}$, which represents volumes of evaporation loss $P_{e v}$. That all depend on the monthly temperature average air $t^{\circ}$ and the average area of the water plan $\bar{\Omega}$ :

$$
P_{e v}=P_{r, t}-P_{\mathrm{inf}}^{(i)}
$$

The evaporation volume $P_{e v}$ is equal to the product of the blade evaporated $E_{e v}$ by the area of the water plan $\bar{\Omega}$, either:

$$
P_{e v}=E_{e v} \bar{\Omega}
$$

Where: the plan evaporated for temperature average data $t^{\circ}$, admit proportional with temperature average data $t^{\circ}$. The calculus expressed:

$$
E_{e v}\left(t^{\circ}\right)=\lambda t^{\circ}
$$

The giving calculation for different successive values $P_{f i l}{ }^{(i)}=\gamma^{(i)} \bar{V}$ determinate the values of evaporation. These calculation stop when it reaches a better correlation between $E_{e v}$ and $t^{\circ}$. The graph below develops the procedure for separation, by filtration $P_{f i l}=\gamma \bar{V}$ and evaporation losses $P_{e v}$. 


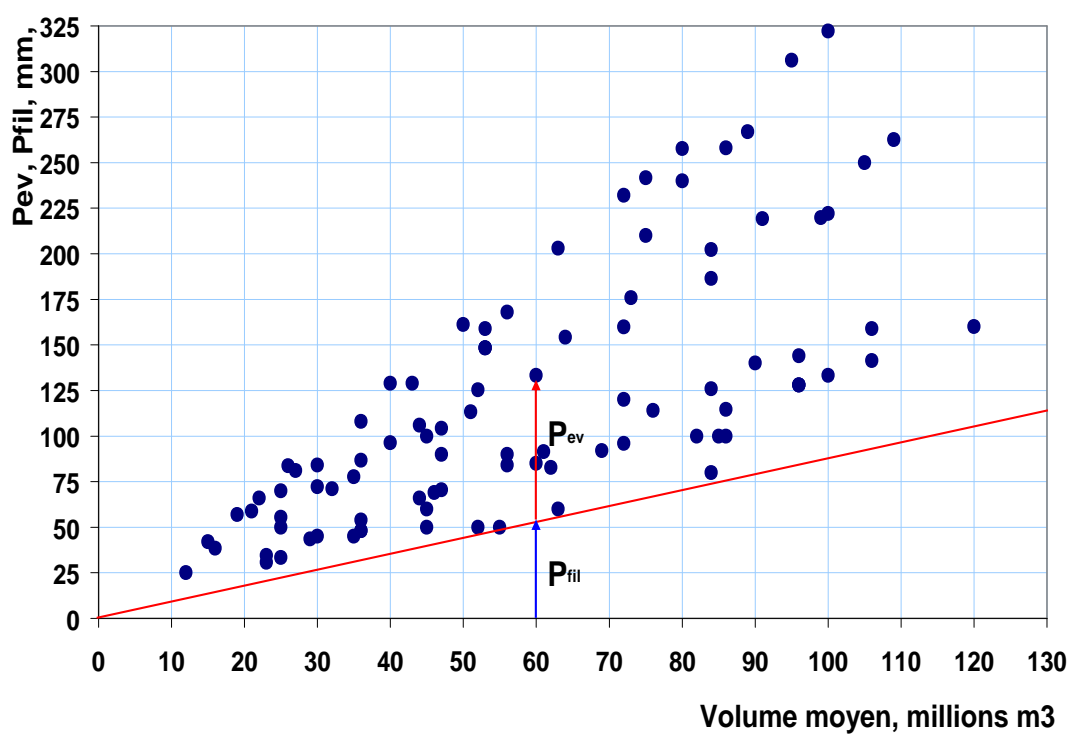

Fig.2. The dependence of water loss in the volume of water in the dam

The estimate of losses by evaporation $P_{e v}$ must match the minimum average frequency $\bar{P} \%_{\text {min }}$ of the worst monthly temperature average the most favorable ( $P=25 \%$ ).

\section{ESTABLISHMENT OF DIAGRAM OF OPERATION}

Hydrological operation involves managing water stored in the dam, taking into account the probable additional contributions that allergens increase the volume of water store and monthly refunds $R_{s,{ }_{i+1}}$, knowing that the volume of refund remains consistent with the regime of irrigation. By replacing the model of flow $m$ and those losses by seepage $\gamma$ and evaporation $\lambda$, in the hydrological balance equation (1), and after a few transformations, it gets the expression of the volume of water in the dam at the end of interval time $i+1$ :

$$
V_{i+1}=V_{i}+P_{i+1,75 \%} \cdot \bar{\Omega}+E_{i+1,75 \%}-R_{s, i+1}-P_{e v, i+1}-P_{f i l, i+1}
$$

Or in the form:

$$
V_{i+1}=\left(\frac{1-B}{B}\right) V_{i}+\frac{2}{B}\left(E_{i+1,75 \%}-R_{s, i+1}\right)
$$

With:

$B=2-a_{V_{i}} P_{i+1,75 \%}+a_{V_{i}} \lambda t^{\circ}{ }_{i+1,25 \%}+\gamma$

$V_{i}$ - Volume of water at the end of the month $i$;

$V_{i+1}$ - Volume of water at the end of the month $i+1$; 
$P_{i+1,75 \%}$ - Monthly average rainfall maximum frequency $P=75 \%$;

$E_{i+1,75 \%}$ - Monthly mean maximum flow-rate $P=75 \%$;

$t^{\circ}{ }_{i+1,25 \%}$ - Air temperature, minimum average frequency $P=25 \%$.

$R_{s, i+1}$ - The return for the month $i+1$.

With the help of calculus (10), it process a calculation in chronological reverse of emptying of dam during the months of irrigation, it is to say since the dead volume $V_{\text {mort }}$ and up to strong volume $V_{\text {util }}$ [8]. For various irrigation schemes, there are curves different from references, which will serve as exploitation guide, because we must always maintain the volume of water in the dam, higher or equal than the one indicate by the curve any data.

Otherwise, we can construct exploitation curves, for different levels of hydrolicite for the year of good water conditions with maximum monthly contribution, the operator may increase the refund and remit the surplus flow without prejudice to the system of irrigation in the coming month. For the year with bad hydrolicite, with minimum monthly contributions, it can estimate the deficit that undergoes the refund during the coming months. Moreover reserves may be exhausted before term.

Figure 3 shows the normal operating curve (blue) and operating curves in terms of abundance (green) and deficit (red).

\section{Volume d'eau, $\mathbf{m}^{3}$}

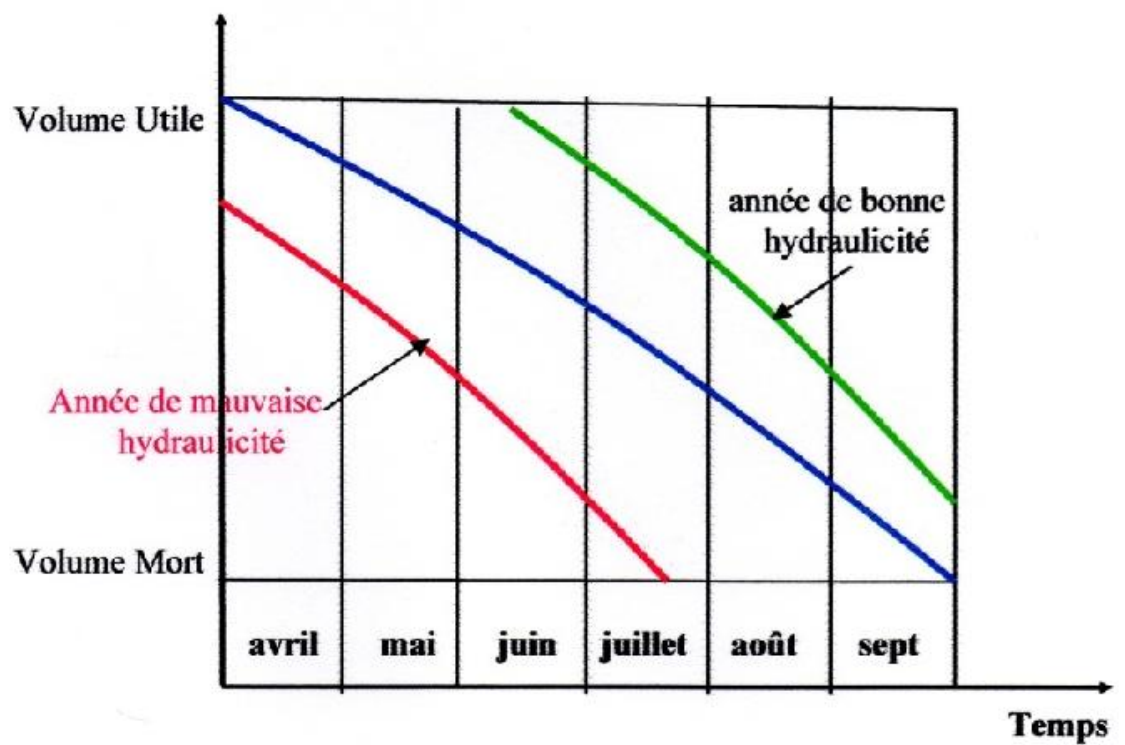

Fig.3. The curves of dam 


\section{CONCLUSION}

The optimal operation of a small dams based on monthly water balance, must use the forecast probabilities hydra metrological. The identification of the parameters of the model of the flow is easily feasible with common hydrological data. The choice of values of calculating frequencies, weather (monthly rainfall and temperature) components must minimize the risk of deficits of the return of the water of irrigation. The establishment of a graph of operating with these three branches facilitate the management of waters of the dam.

\section{REFERENCES}

[1] еф ни . . опросы регион льной гидрологии. водочный сток. иев, 1989, 132 стр.

[2] орошков . . идрологические р счеты. енингр д, идрометеоизд т, 1979, 631 стр.

[3] елезняк . . егулиров ние п водочного сток . енингр д, идрометеоизд т, 1965, 326 стр.

[4] Ladjel Mahmoud:" The methods for determining the hydrological characteristics of small watersheds. "Communication, National Seminar on Withholding Collinear, Sétif, 1986.

[5] Ladjel Mahmoud" Contribution to the calculation of dams to protect urban areas against storm floods" 3rd National Seminar on Water Resources, 26,27 and 28 October 1998, Biskra.. [6] Ladjel Mahmoud" Forecast streamflow during low flow". Scientists days INRGREF, Hammamet, 29 and 30 October 1998, Tunisia.

[7] Ladjel Mahmoud" Projections of monthly flow in the Ighil-Emda dam. Workshop on dams. I.G.C. Abu Bakr University Belkaïd, 30 and 31 May 1999, Tlemcen.

[8] лешков . .. егулиров ние речного сток -водохозяйственные росчеты-. енингр д, идрометеоизд т, 1975, 558 стр.

[9] околовский . . ечного сток. енингр д, идрометеоизд т, 1968, 539 стр. 83-90. 